\title{
PENGEMBANGAN MEDIA MONERGI (MONOPOLI ENERGI) UNTUK MENUMBUHKAN KEMAMPUAN PEMAHAMAN KONSEP IPA SISWA SD
}

\author{
Siti Ulfaeni' ${ }^{1)}$; Husni Wakhyudin ${ }^{2)}$; Henry Januar Saputra ${ }^{3)}$ \\ Universitas PGRI Semarang \\ email: ${ }^{1}$ ulvashifa@gmail.com
}

\begin{abstract}
This research applied media development monergi (monopoli energi) which helps the students understanding of science and how implementation media monergi be able to increase the students understanding in science.This subject of the research were students $3 B$ grade, academic year 2016/2017 with total students 38. The data from this research calculated by pretest and also posttest, questionnaire responds the students about the media. Questionnaire from expert validations media and also material. The scoring expert validations media and also material trough 2 steps, found from presentation from validation 1 and 2 that will be found the average presentation $77 \%$ with the criteria "valid" and 98\% with the criteria "perfect", from the expert validations 1 and 2 we found the results that were $92 \%$ and $98 \%$ with the criteria is "perfect", and the result student responds about media monergi is 93\% with "perfect" criteria. The result of student understanding concept pre-test was 49\% and post-test was $84 \%$ there is enhancement. Therefore the capability of students understanding in science concept was increased. The conclusion was media learning of monergi valid to increase students understanding science concept the students 3B SDN Pedurungan Kidul 02 Semarang.
\end{abstract}

Keywords: research and development, monergi (monopoli energi), the ability in concept understanding

\section{PENDAHULUAN}

Keterampilan

siswa

dapat

dikembangkan, dapat diasah ketika siswa sudah mulai memasuki bangku sekolah. Ketika berada dibangku sekolah dasar potensi ini dapat dipupuk dengan pembelajaran yang menarik sesuai dengan materi pembelajaran maka dapat ditunjang dengan menggunakan media yang kreatif dan inovatif. Agar perolehan hasil pembelajaran yang diinginkan dapat meningkatkan kemampuan pemahaman konsep siswa. Kemampuan pemahaman konsep itu sangat perlu diberikan kepada siswa karena memudahkan ingatan siswa terhadap mata pelajaran yang diajarkan oleh guru.

Menurut Aqib (2013: 50), media pembelajaran adalah segala sesuatu yang dapat digunakan untuk menyalurkan pesan dan merangsang terjadinya proses belajar pada pembelajar (siswa). Sehingga media pembelajaran merupakan perantara atau pengantar pesan dari guru kepada siswa agar mempermudah penyerapan materi pembelajaran yang diajarkan (Kustandi, 2013: 14) . Penggunaan media pembelajaran sangat penting terutama dalam mengajar siswa Sekolah Dasar yang rata-rata berusia 7-12 tahun.

Pada usia tersebut manusia memasuki tahap operasional konkret, yaitu telah memiliki kemampuan berpikir logis akan tetapi dengan dibantu benda-benda yang bersifat konkret atau nyata, artinya dalam kegiatan pembelajaran siswa memerlukan benda nyata yang dapat memudahkan ia berpikir. Benda nyata dalam kegiatan pembelajaran berupa media pembelajaran 
yang dapat membantu guru dalam menyampaikan materi sehingga tujuan pembelajaran dapat tercapai secara maksimal. Kemampuan guru dalam merancang dan menerapkan media pembelajaran merupakan kunci dari keberhasilan proses pembelajaran.

Media pembelajaran diharapkan membantu dalam proses pembelajaran, juga memudahkan siswa membentuk konsep nyata. Media pembelajaran yang bervariasi itu diterapkan dengan desain khusus yang berbeda dengan media sebelumnya maupun dari media yang sudah ada, dan memiliki langkah-langkah yang menarik, membuat siswa aktif. Keaktifan siswa dilihat dari cara siswa mengikuti petunjuk yang diminta guru dengan baik dan sesuai. Pembelajaran yang digunakan di kelas rendah harus ditunjang dengan media konkrit yang mendukung dan sesuai dengan materi pembelajaran.

Hasil pembelajaran yang diperoleh siswa tentunya tidak semuanya mendapat nilai yang diharapkan sesuai dengan KKM yang telah ditentukan. Media yang menarik dan didesain sedemikian rupa dapat menarik perhatian dan simpati siswa ketika mengikuti pembelajaran. Namun media yang menarik perhatian siswa yaitu media yang nyata dan konkrit, maksudnya media yang membantu siswa untuk memahami suatu pembelajaran yang mudah dipahami dan kontekstual yang berkaitan dengan kehidupan nyata siswa. Benda nyata dalam pembelajaran memudahkan dan membantu guru dalam menyampaikan materi sehingga tujuan pembelajaran yang diharapkan dapat terlaksana dengan maksimal. Kemampuan guru merancang dan menerapkan media pembelajaran merupakan kunci dari keberhasilan proses pembelajaran yang menyenangkan.
Praktek dalam pembelajaran kelas rendah, guru harus menggunakan media yang menarik perhatian siswa agar berpusat pada kegiatan pembelajaran karena kelas rendah masih membutuhkan media konkret, sama juga dengan kelas tinggi guru juga membutuhkan media sebagai alat transfer materi kepada siswa dengan mudah dan menarik perhatian siswa, agar perhatian siswa berpusat pada kegiatan pembelajaran, meskipun kelas tinggi sudah mampu berpikir secara abstrak namun dengan penggunaan media akan lebih memudahkan pemahaman materi (Arsyad, 2014). Namun pada kenyataannya guru hanya menggunakan buku acuan dengan media seadanya, buku yang digunakan adalah buku dari pemerintah. menggunakan buku saja tidak efektif jika tidak diimbangi dengan media pembelajaran.

Penggunaan media yang kurang efektif mengakibatkan dampak pada siswa yang kurang aktif. Siswa kurang begitu antusias dalam mengikuti pelajaran dan cenderung melakukan aktifitas-aktifitas yang merugikan siswa itu sendiri. Dalam pembelajaran di kelas IIIB siswa cenderung lebih suka permainan, gambar-gambar berwarna dan menarik. Pembelajaran di kelas rendah guru harus menggunakan media yang nyata dan kongkrit untuk membantu siswa memahami materi yang diajarkan terutama dalam pembelajaran IPA di sekolah dasar yang erat kaitannya dengan kehidupan sehari-hari. Hal ini senada dengan tulisan Desstya dkk (2017: 2) pembelajaran IPA sebaiknya dilakukan dengan discovery learning, yang didasarkan pada aktivitas pengamatan, menginferensi, mengkomunikasikan hasil belajarnya. Aktivitas ini merupakan inti dari keterampilan proses (scientific process) (Samawato, 2010); (Almafdi, 2016). 
Salah satu solusi untuk menangani masalah tersebut dibutuhkan media pembelajaran yang sesuai digunakan kelas rendah khususnya pada kelas III yaitu media pembelajaran monopoli. Monopoli adalah suatu permainan yang dimainkan lebih dari dua orang, Permainan ini lebih menekankan pada menguasai. Maksud menguasai dalam permainan monopoli ini adalah menguasai materi-materi yang akan diajarkan oleh guru. Permainan ini dimodifikasi menjadi media pembelajaran yang menyenangkan sebagai penunjang pembelajaran agar siswa dapat memahami materi yang akan diajarkan oleh guru. Media monopoli lebih disukai siswa dan dapat melatih kejujuran siswa. Siswa kelas rendah lebih suka bermain sambil belajar untuk itu peneliti menggunakan pengembangan media monopoli sebagai penunjang pembelajaran.

Berdasarkan latar belakang yang sudah diuraikan, maka rumusan masalah dari penelitian tersebut adalah: Apakah Pengembangan media Monergi (Monopoli Energi) Valid menumbuhkan kemampuan pemahaman konsep IPA dan Bagaimana implementasi media Monergi (Monopoli Energi) Mampu menumbuhkan kemampuan pemahaman konsep IPA siswa kelas IIIb SDN Pedurungan Kidul 02 Semarang.

Husna (2009: 15) permainan monopoli merupakan salah satu jenis permainan papan yang bertujuan untuk mengumpulkan kekayaan dan menguasai komplek-komplek pada papan permainan. Media monopoli merupakan media yang dapat digunakan dengan cara bermain sehingga memberi siswa situasi-situasi yang menyenangkan, tidak membosankan dan mempermudah sisiwa dalam menjawab pertanyaan.

Media permainan monopoli merupakan salah satu media yang dapat menimbulkan kegiatan belajar yang menarik dan membantu suasana belajar menjadi menyenangkan. Permainan monopoli digunakan sebagai media pembelajaran karena kebanyakan siswa sudah mengetahui permainan tersebut. Sehingga kegiatan pembelajaran akan lebih menyenangkan dan memperoleh banyak pengetahuan dan materi yang dipelajari. Tujuan utama dari permainan monopoli pembelajaran ini sebenarnya sama dengan permainan monopoli pada umumnya yaitu menguasai, maksud dari penguasai adalah menguasai ilmu pengetahuan yang terdapat pada permainan monopoli tersebut.

Keistimewaan dari media permainan monopoli ini yang membedakan dari permainan monopoli pada umumnya yaitu terdapat di dalam kartu dana umum, kartu kesempatan dan dikembangkan lagi kartu hukuman dan kartu pembelian yang terdapat di permainan monopoli. Gambar-gambar yang terdapat pada kotak monopoli sesuai dengan materi yang akan diajarkan. Keistimewaan dari media monopoli ini juga terdapat pada papan yang terbuat dari kaya dan dilapsi dengan MMT, papan tersebut digunakan sebagai meja dan dapat dilipat agar praktis di bawa kemana-mana. Papan yang terbuat dari kayu dilapisi dengan MMT monopoli sehingga MMT monopoli tersebut tidak mudah rusak dan dapat di gunakan kembali.

Pemahaman menurut Bloom (dalam Ahmad Susanto, 2013: 6) diartikan sebagai kemampuan untuk menyerap arti dari materi atau atau bahan yang dipelajari. Pemahaman menurut Bloom ini adalah seberapa besar siswa mampu menerima, menyerap dan memahami pelajaran yang diberikan oleh guru kepada siswa, atau sejauh mana siswa dapat memahami seta mengerti apa yang siswa baca, yang dilihat, yang dialami, atau 
yang siswa rasakaan berupa hasil penelitian atau observasi langsung yang siswa lakukan.

Carin Dan Sund (dalam Ahmad Susanto, 2013: 7-8) bahwa pemahaman dapat dikategorikan kepada beberapa aspek, dengan kriteria-kriteria sebagai berikut :

a. Pemahaman merupakan kemampuan untuk menerangkan dan menginterprestasikan sesuatu: ini berarti bahwa seseorang yang telah memahami sesuatu atau telah memperoleh pemahaman akan mampu menerangkan atau menjelaskan kembali apa yang telah diterima.

b. Pemahaman bukan sekedar mengetahui yang biasanya sebatas mengingat kembali pengalaman dan memproduksi apa yang pernah dipelajari.

c. Pemahaman lebih dari sekedar mengetahui karena pemahaman melibatkan proses mental yang dinamis, dengan memahami akan mampu memberikan uraian dan penjelasan yang lebih kreatif, tidak hanya memberikan gambaran dalam suatu contoh saja tetapi mampu memberikan gambaran yang lebih luas dan baru sesuai dengan kondisi saat ini.

d. Pemahaman merupakan suatu proses bertahap yang masing masing tahap mempunyai kemampuan sendiri, seperti menerjemahkan, menafsirkan, ekstrapolasi, aplikasi, analisis, sintesis, dan evaluasi.

Menurut Badan Standar Nasional Pendidikan (2006) indikator pemahaman konsep adalah sebagai berikut :

a. Menyatakan ulang suatu konsep

b. Mengklarifikasikan objek-objek menurut sifat- sifat tertentu c. Memberi contoh dan non-contoh dari konsep

d. Mengembangkan syarat perlu dan syarat cukup suatu konsep

e. Menggunakan, memanfaatkan, dan memilih prosedur atau operasi tertentu

f. Mengaplikasikan konsep atau pemecahan masalah

Sains berasal dari kata science yaitu istilah yang mengacu pada masalah-masalah kealaman (natural). Secara sederhana sains didefinisikan sebagai ilmu pengetahuan yang mempelajari tentang gejala-gejala alam. Sains juga merupakan bagian dari ilmu pengetahuan yang terdiri dari fakta-fakta, konsep-konsep, prinsip-prinsip, dan teori-teori yang merupakan produk dari proses ilmiah.

Setiap pembelajaran IPA dimulai dengan judul yang mengacu pada masalah utama yang diajarkan, Dalam kurikulum konsep telah diberikan langsung pada setiap pembelajaran. Pada pembelajaran IPA sekolah dasar diperlukan pengetahuan dasar mengenai konsep yang terkandung dalam setiap unit pembelajaran. Sebelum pembelajaran dimulai guru IPA menginformasikan kepada peserta didik tujuan- tujuan yang diharapkan, yang kemudian akan menjadi capaian setelah pelajaran selesai.

Dalam Samatowa (2011: 19-20 paparan dari pengertian kemampuan pemahaman konsep IPA dapat disimpulkan bahwa kemampuan pemahaman konsep IPA yaitu siswa mampu menyerap dan memahami pelajaran tentang ilmu pengetahuan yang mempelajari gejala-gejala alam.

\section{METODE PENELITIAN}

Jenis penelitian ini adalah penelitian dan pengembangan atau Research and Development (R\&D). Metode ini merupakan 
rangkaian proses atau langkah-langkah mengembangkan suatu produk atau menyempurnakan suatu produk yang sudah ada agar dapat dipertanggung jawabkan, metode pengembangan ini memiliki fungsi yang sangat luas jika dapat dikembangkan di dalam masyarakat, maka diperlukannya penelitian keefektifan produk yang dikembangkan (Sugiyono, 2015).

Prosedur pengembangan media ini dilakukan berdasarkan tahapan langkahlangkah pengembangan model desain sistem pembelajaran model Borg and Gall, yang meliputi penelitian dan pengumpulan informasi, perencanaan penelitian, pengembangan bentuk awal produk, uji lapangan awal, revisi produk, uji lapangan awa, revisi produk operasional, uji lapangan operasional, revisi produk akhir, desiminasi dan implementasi. Peneliti hanya akan menggunakan 5 (lima) tahapan.

Analisis data yang digunakan yaitu analisis dekriptif kualitatif dan deskriptif kuantitatif. Data kualitatif berupa komentar dan saran perbaikan produk dari ahli media pembelajaran dan ahli materi pembelajaran. Sedangkan data kuantitatif berupa skor penilaian angket ahli media, angket ahli materi, angket respon siswa, dan hasil kemampuan pemahaman konsep IPA dengan hasil Pretest dan Posttest.

Ujicoba media pembelajaran hasil pengembangan dilaksanakan di SDN Pedurungan Kidul 02 Semarang pada tanggal 23 dan 24 Mei 2017. Subjek penelitian ini adalah seluruh siswa kelas IIIb SDN Pedurungan Kidul 02 Semarang. Sesuai dengan tahapan penelitiannya, maka akan dilaksanakannya beberapa tahapan proses pengambilan data. Dalam penelitian ini dilakukan ujicoba terlebih dahulu media
Monergi (Monopoli energi) dengan jumlah 38 siswa kelas IIIb.

Tahap Perencanaan media monergi (monopoli energi) yang di dalamnya mencangkup pemilihan media yang tepat dan akan dijadikan sebagai penunjang materi pembelajaran. Pada tahap perencanaan (planning), peneliti memilih pengembangan media Monergi (Monopoli energi).

Tujuan dari penelitian pengembangan media Monergi (Monopoli energi) ini agar dapat digunakan sebagai penunjang pembelajaran pada materi sumber energi dan kegunaannya.

Adapun beberapa komponen yang masuk dalam media monopoli energi diantaranya:

1) Papan permainan yang terbuat dari kayu berukuran $\pm 60 \times 60 \mathrm{~cm}$, yang berfungsi sebagai papan atau tatakan dalam permainan.

2) Desain Monopoli yang terbuat dari MMT, hanya saja pada gambar monopoli diganti dengan gambar yang sesuai materi dan pada kartu yang biasa berisi 2 kartu yaitu kartu dana umum dan kartu kesempatan kemudian dikembangkan menjadi 4 kartu yaitu kartu dana umum, karu kesempatan, kartu pembelian dan kartu hukuman. Monopoli ini berukuran $\pm 60 \times 60 \mathrm{~cm}$.

3) Kotak kecil untuk meletakan kartu permainan berukuran $\pm 10 \times 10 \mathrm{~cm}$

4) 2 Dadu dan 4 bidak

5) Kartu permainan, berupa potonganpotongan kartu yang berukuran $\pm 6 \times 9$ $\mathrm{cm}$, yang berisi pertanyaan sesuai dengan materi.

6) Kartu aturan permaina atau langkahlangkah dalam permainan monergi (monopoli energi). 


\section{HASIL DAN PEMBAHASAN}

Uji keefektifan media dilakukan di SDN Pedurungan Kidul 02 Semarang, siswa kelas IIIb dengan jumlah 38 siswa. Hasil uji keefektifan media pembelajaran monergi berdasarkan hasil pretest-posttest dan angket respon siswa terhadap media pembelajaran monergi. Soal pretest-posttest diberikan kepada siswa pada saaat ujicoba. Sebelum menggunakan media monergi siswa terlebih dahulu mengerjakan soal pretest kemudian siswa mengikuti pelajaran Ilmu Pengetahuan Alam dengan menggunakan media monergi. Kemudian pada akhir penggunaan media, siswa mengerjakan soal posttest sehingga dapat dilihat perbedaan antara hasil pretest dengan hasil posttest.

\section{Analisis Implementasi Kemampuan pemahaman Konsep}

Implementasi kemampuan pemahaman konsep dapat dilihat dengan adanya peningkatan dari hasil pretest dan posttest. Hasil pretest menunjukan bahwa nilai terendah yang diperoleh siswa adalah 30 dan nilai tertinggi mencapai 90 dengan jumlah soal sebanyak 10 butir soal, kemudian dihitung dengan cara dikalikan 10 setiap butir soal benar. Nilai rata-rata siswa mencapai 48,95. Pada pretest ini siswa yang tidak mencapai KKM sebanyak 36 siswa sedangkan siswa yang sudah mencapai KKM sebanyak 2 siswa dengan jumlah persentase keseluruhan 49\%. Sedangkan hasil posttest menunjukan bahwa nilai terendah yang diperoleh siswa adalah 70 dan tertinggi 100 dengan jumlah soal sebanyak 10 soal benar, kemudian dikalikan 10. Nilai rata-rata yang diperoleh siswa mencapai 83,95. Jumlah persentase keseluruhan dari nilai posttest mencapai $84 \%$. Skor gain (gain ternormalisasi) berada di 0,6856 di kategori "Sedang".
Dengan demikian peneliti dapat menarik kesimpulan bahwa implementasi kemampuan pemahaman konsep dapat meningkat dengan adanya nilai yang diperoleh siswa mencapai nilai KKM yang telah ditentukan sehingga siswa memahami materi pembelajaran IPA yang telah diajarkan. Nilai gain ternormalisasi berada di kategori "Sedang" dengan rentang 0,6856 . Sehingga kemampuan pemahaman konsep IPA dapat meningkat setelah menggunakan media pembelajaran Monergi (Monopoli Energi) materi energi dan pengaruhnya dalam kehidupan sehari-hari pada materi bentuk-bentuk energi dan contohnya.

\section{Analisis Respon Siswa Terhadap Media Monergi (Monopoli Energi)}

Analisis respon siswa terhadap media Monergi (Monopoli Energi) untuk menumbuhkan kemampuan pemahaman konsep IPA siswa kelas IIIb SDN Pedurungan Kidul 02 Semarang pada mata pelajaran IPA dapat dilihat dari persentase berdasarkan hasil yang didapat dari penilaian hasil respon yang dikerjakan oleh 38 siswa SDN Pedurungan Kidul 02 Semarang, maka diketahui rentang nilai $81 \%-100 \%$ dari $93 \%$ termasuk dalam kriteria " Tinggi”.

Penelitian dan pengembangan atau dalam bahasa Inggrisnya Research and Development adalah penelitian pengembangan untuk menghasilkan suatu produk atau menyempurnakan produk lain. Pada tahap pengembangan yang dilakukan berdasarkan langkah-langkah Borg and Gall.

Pengembangan media Monergi untuk kelas IIIb berdasarkan wawancara dengan guru kelas IIIb, memberikan angket kebutuhan guru tentang media pembelajaraan dan siswa yang ditemukan di kelas IIIb SDN Pedurungam kidul 02 
semarang. Dari data yang diperoleh maka disusun desain produk yang akan dibuat, yang dilakukan sesuai dengan penelitian dan pengumpulan informasi pada materi pembelajaran bentuk-bentuk energi dan contohnya dalam kehidupan sehari-hari.

Tahap selanjutnya pengembangan yaitu membuat media pembelajaran sesuai dengan desain, kemudian dilakukan validasi media pembelajaran dengan beberapa revisi dari hasil saran dan komentar.Dengan validasi media pembelajaran dilakukan 2 tahap yaitu tahap 1 awal mengajukan produk, tahap 2 tahap revisi produk.

Kemudian dilakukan validasi materi pembelajaran dilakukan oleh ahli materi pembelajaran dengan melalui tahap 2 yaitu tahap 1 mengajukan produk dan tahap 2 revisi produk, hal ini diketahui bahwa produk tidak perlu melakukan revisi lagi karena sudah mencapai kriteria "Sangat Valid". Dalam tahap oleh ahli diperoleh saran dan komentar. Saran dan komentar tersebut dijadikan pedoman untuk merevisi produk. Tahap uji lapangan awal yaitu mengujicobakan produk yaitu media pembelajaran. Tahap revisi hasil iji coba yaitu menilai kemampuan pemahaman konsep IPA dengan diberikan tes sebelum menggunakan media dan sesudah menggunakan media (pretest dan posttest) serta mengetahui respon siswa terhadap media pembelajaran. Validasi dilakukan oleh ahli media pembelajaran, ahli materi pembelajaran, berupa cheklist dan respon siswa dengan memilih jawaban "Ya" atau "Tidak".

Tujuan pengembangan media monergi yaitu untuk meningkatkan kemampuan pemahaman siswa agar dapat membantu siswa dalam proses pemerolehan pengetahuan mata pelajaran Ilmu
Pengetahuan Alam. Kemudian diujicobakan oleh peneliti di SDN Pedurungan Kidul 02 Semarang.

Berdasarkan penilaian media pembelajaran monergi pada validasi tahap akhir yang dilakukan oleh ahli media pembelajaran didapat persentase sebanyak 98\% dengan kriteria "Sangat Valid" dan ahli materi pembelajaran didapat hasil persentase penilaian sebanyak 98\% dengan kriteria "Sangat Valid", selanjutnya produk diujicobakan pada siswa kelas IIIb SDN Pedurungan Kidul 02 Semarang, untuk mengetahui tingkat persentase hasil kemampuan pemahamn konsep IPA siswa dan persentase respon siswa mengenai produk media pembelajaran yang dikembangkan.

Berdasarkan data yang diperoleh, hasil penilaian hasil kemampuan pemahamn konsep IPA siswa posttest sebanyak 84\% dengan kriteria "Valid". Sehingga dikatakan siswa berminat dengan mata pelajaran Ilmu Pengetahuan Alam dan respon siswa hasil persentase sebanyak 93\% dengan kriteria "Sangat Tinggi".

Hasil dari validasi tersebut menunjukkan bahwa media pembelajaran Monergi (monopoli energi) dalam materi bentukbentuk energi dan contohnya dalam kehidupan sehari-hari untuk siswa SD kelas IIIb berada pada kriteria "Sangat Valid" sehingga dapat dinyatakan bahwa media pembelajaran Monergi (monopoli energi) dalam materi energi dan pengaruhnya dalam kehidupan sehari-hari pada materi pokok bentuk-bentuk energi dan contohnya dalam kehidupan sehari-hari mampu menumbuhkan kemampuan dan pemahaman konsep IPA siswa kelas IIIb SDN Pedurungan Kidul 02 Semarang. 


\section{SIMPULAN DAN SARAN}

Hasil dari penelitian dan pengembangan yang telah dipaparkan, maka dapat disimpulkan bahwa pengembangan media Monergi (Monopoli Energi) mampu menumbuhkan kemampuan pemahaman konsep IPA mata pelajaran bentuk-bentuk energi dan contohnya. Hal tersebut dapat dibuktikan dengan alasan sebagai berikut:

1. Pengembangan media Monergi (Monopoli Energi) valid menumbuhkan kemampuan pemahaman konsep IPA siswa kelas IIIb berdasarkan hasil validasi dengan ahli media dari validasi 1 dan 2 didapat rata-rata persentase yaitu $77 \%$ dengan Kriteria "Valid" dan 98\% dengan Kriteria "Sangat Valid" Hasil validasi ahli materi dari validasi 1 dan 2 didapat rata-rata persentase yaitu $92 \%$ dan 98\% dengan Kriteria "Sangat Valid". Sehingga media Monergi (Monopoli Energi) Sangat Valid menumbuhkan kemampuan pemahaman konsep IPA siswa kelas IIIb SDN Pedurungan Kidul 02 Semarang.

2. Implementasi media Monergi (Monopoli Energi) mampu menumbuhkan kemampuan pemahaman konsep IPA siswa kelas IIIb berdasarkan hasil hasil persentase respon siswa terhadap media Monergi (Monopoli Energi) dengan presentase 93\% dengan Kriteria "Sangat Valid". Dan hasil persentase pretest dan posttest untuk menumbuhkan kemampuan pemahaman konsep IPA siwa kelas IIIb dengan hasil presentase pretest $49 \%$ dan $84 \%$. Sehingga kemampuan pemahaman konsep IPA dapat meningkat.
Setelah dilakukan penelitian, saran yang dapat peneliti sampaikan adalah sebagai berikut:

1. Media Monergi (Monopoli Energi) dapat dikembangakan menjadi media permainan yang digunakan dalam proses pembelajaran yang menyenangkan dengan materi yang sesuai dan menarik perhatian siswa sehingga dapat menumbuhkan kemampuan siswa dalam pembelajaran di sekolah.

2. Guru dapat menggunakan media Monergi (Monopoli Energi) untuk memberikan suasana belajar siswa yang menyenangkan.

Penelitian pengembangan ini memiliki keterbatasan yaitu hanya dinilai oleh ahli media pembelajaran dan ahli materi pembelajaran. Selain itu materi yang diberikan hanya terbatas yaitu pada mata pelajaran Ilmu Pengetahuan Alam dengan materi energi dan pengaruhnya dalam kehidupan sehari-hari dengan pokok materi bentuk-bentuk energi dan contohnya dalam kehidupan sehari-hari. 


\section{DAFTAR PUSTAKA}

Arsyad. 2014. Media Pembelajaran. Jakarta: Rajawali Pers.

Almafdi, Feni Imsa. 2016. "Keefektifan Model STAD Berbantu Media Audio Visual Terhadap Kemampuan Pemahaman Konsep IPA Siswa Kelas IV SD Negeri Kreman 01 Tegal.” Skripsi. Universitas PGRI Semarang.

Aqib, Zainal. 2013. Model-Model, Media, Dan Strategi Pembelajaran Kontekstual (Inovatif). Bandung: Yrama Widya.

Desstya, dkk. 2017. Refleksi Pendidikan IPA Sekolah Dasar di Indonesia. (Relevansi Model Pendidikan Paulo Freire dengan Pendidikan IPA di SD). Jurnal Profesi Pendidikan $\begin{array}{lllll}\text { Dasar, } & \text { Vol. } & 4 & \text { No.1, }\end{array}$ http://journals.ums.ac.id/index.php/ppd/article/view/2745/3444

Husna, M. 2009. 100+ Permainan Tradisional Indonesia Untuk Kreatifita, Ketangkasan Dan Keakraban. Yogyakarta: Cv Andi Offset.

Kustandi, Cecep \& Bambang Sutjipto. 2013. Media Pembelajaran Manual Dan Digital. Bogor: Penerbit Ghalia Indonesia.

Samawato. 2010. Pembelajaran IPA Di Sekolah Dasar. Jakarta: Indeks.

Sugiyono. 2015. Metode Penelitian Tindakan Komperhensif. Bandung: Alfabeta

Susanto, Ahmad. 2013. Teori Belajar \& Pembelajaran Di Sekolah Dasar. Jakarta: Prenadamedia Group. 